\title{
Ingerencja ZSRR w życie kulturalne Polski (1944-1953)
}

Wiktor Choriew 
nAPISS Seria VI 2000

\section{Wiktor Choriew}

\section{Ingerencja ZSRR w życie kulturalne Polski (1944-1953)}

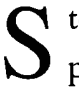
tosunki pomiędzy Polską a Rosją zawsze układały się pod potężnym wpływem sytuacji politycznych, które zaostrzały się w latach przełomów. Na początku XVII wieku określały je wydarzenia smuty, w XIX wieku — polskie powstania narodowowyzwoleńcze, w wieku XX - przewrót październikowy w Rosji, wojna polsko-radziecka 1920, czwarty rozbiór Polski we wrześniu 1939 i późniejsze tego konsekwencje.

Do okresów przełomowych należą także pierwsze lata po drugiej wojnie światowej, kiedy ujawniło się dążenie ZSRR do sowietyzacji Polski. Wyzwolenie Polski przez armię radziecką uchroniło naród polski przed biologiczną zagładą, lecz nie dało mu możliwości swobodnego decydowania o swoich losach. Związek Radziecki za pomocą różnych środków, nie wyłączając terroru policyjnego, narzucił Polsce własny system polityczny.

Pod koniec lat czterdziestych w Polsce, jak i w większości krajów Europy środkowej i południowowschodniej, utrwalił się reżim komunistyczny typu stalinowskiego. Olbrzymią rolę w takim biegu wydarzeń odegrała obecność na terenie kraju wojsk radzieckich, a także doradców ze Związku Radzieckiego, działających w armii polskiej i organach bezpieczeństwa, jak również $\mathrm{w}$ innych polskich instytucjach politycznych i ekonomicznych, oraz nacisk polityczny kierownictwa ZSRR na władze polskie i organizowane przez nie „przekucie” ideologiczne ludności polskiej.

O strategicznych zamierzeniach władz radzieckich wobec Polski i mechanizmie ich realizacji można sądzić na podstawie niektórych dostępnych dzisiaj dokumentów archiwalnych, które omówię pokrótce w moim artykule. 
Część omawianych dokumentów opublikowana została ostatnio przez Instytut Słowianoznawstwa Rosyjskiej Akademii Nauk ${ }^{1}$, inne znalazłem w różnych archiwach radzieckich.

Dokumenty te wskazują, że plany ZSRR co do przyszłości Polski przemyśliwane były jeszcze podczas wojny. 10 stycznia 1944 roku jeden z wysoko postawionych dyplomatów radzieckich J. Majski w memoriale pod adresem W. Mołotowa pisał o losach powojennej Polski:

Celem ZSRR powinno być stworzenie Polski niezależnej i zdolnej do życia, nie jesteśmy jednak zainteresowani narodzeniem się Polski zbyt wielkiej i zbyt silnej. W przeszłości Polska prawie zawsze była wrogiem Rosji. Czy przyszła Polska będzie prawdziwym przyjacielem ZSRR (przynajmniej za życia najbliższego pokolenia), nikt $z$ pewnością orzec nie może. Wielu w to wątpi, i sprawiedliwość wymaga stwierdzić, że dla takich wątpliwości istnieją wystarczające podstawy. Biorąc pod uwagę powyższe, należy ostrożniej kształtować Polskę powojenną w możliwie minimalnych rozmiarach, ściśle przestrzegając zasady granic etnograficznych ${ }^{2}$.

Później plany te modyfikowano. Przedsięwzięto cały szereg kroków, zmierzających do ustanowienia w Polsce reżimu komunistycznego na modłę radziecką. Nie będę wspominał o politycznych, policyjnych i ekonomicznych formach nacisku na Polskę, zatrzymam się jedynie na niektórych dokumentach, dających pojęcie o roli tak zwanego czynnika radzieckiego w życiu kulturalnym Polski w latach 1944-1953. Okres ten zamyka rok śmierci Stalina, po której zaczyna się długotrwała agonia stworzonego przez niego systemu.

Radziecki mechanizm ideologicznej obróbki świadomości masowej w Polsce i wpływu na rozwój kultury polskiej pracował na rzecz propagandy polityki ZSRR, ideologii komunistycznej, wzorów kultury radzieckiej. Częściami tego mechanizmu były ambasada radziecka, Wszechzwiązkowe Towarzystwo Łączności Kulturalnej z Zagranicą (WOKS), Radzieckie Biuro Informacyjne (Sowinformbiuro), wydawnictwo literatury w językach obcych, zjednoczenie Mieżdunarodnaja Kniga, Centrala Eksportu Filmu Radzieckiego (Soweksportfilm), redakcja polska radia radzieckiego, Komisja Zagraniczna Związku Pisarzy Radzieckich, Towarzystwo Przyjaźni Polsko-Radzieckiej i inne urzędy.

Od pierwszych dni istnienia powojennej Polski w sprawy polskie aktywnie ingeruje ambasada radziecka, która pouczała polskich działaczy politycznych, w tym również w zakresie propagandy i kultury.

' Zob. NKWD i polskoje podpolie 1944-1945 (Po „osobym papkam” I. W. Stalina), Moskwa 1994; Wostocznaja Jewropa $w$ dokumientach rossijskich archiwow 1944-1953, t. 1: 1944-1948, Moskwa-Nowosibirsk 1997; t. 2: 1949-1953, Moskwa-Nowosibirsk 1998; Sowietskij faktor w Wostocznoj Jewropie 1944-1953, t. 1: 1944-1948. Dokumienty, Moskwa 1999.

${ }^{2}$ Sowietskij faktor..., op. cit. s. 29-30. 
W rozmowie 1 sierpnia 1945 roku z polskim premierem Osóbką-Morawskim na temat sytuacji politycznej w Polsce radca ambasady Jakowlew zwrócił uwagę Morawskiego na to, że w publikacjach wielu polskich gazet nie docenia się roli działaczy państwowych. Jak donosi Jakowlew w notatce służbowej dla Wyszyńskiego, Morawski zgodził się z krytyką, dodając: „Weźmy na przykład towarzysza Stalina, gra tak olbrzymią rolę...”3.

Nie mniej służalczo o Stalinie wypowiadał się Cyrankiewicz, który w rozmowie z tymże Jakowlewem w sierpniu 1947 roku oświadczyl:

My, socjaliści polscy, uważamy towarzysza Stalina za tak znaczący dla nas autorytet, że rady jego powinny być dla nas linią przewodnią. ${ }^{4}$

Później Bierut zwracał się do Stalina „Kochany i Drogi Towarzyszu Stalinie”, meldując w liście z 15 kwietnia 1950 roku o utworzeniu Sekretariatu Organizacyjnego KC PZPR „według Waszych rad”5.

Ambasada radziecka niejednokrotnie zgłaszała Cyrankiewiczowi różne dezyderaty, za które, jak referuje Jakowlew, ten „szczególnie gorąco dziękował”. Dotyczyło to między innymi wydawnictwa PPS „Wiedza”, o którym w grudniu 1946 roku Jakowlew powiedział Cyrankiewiczowi:

Co do Waszego wydawnictwa partyjnego „Wiedza”, to sami widzicie, że jego działalność w kierunku rozpowszechniania literatury radzieckiej równa się zeru. Tymczasem książka radziecka, w tym literatura na tematy artystyczne, mogłaby sprzyjać zadaniu, które stoi przed PPS, mianowicie zadaniu wychowania na nowo ludności polskiej w duchu przyjaźni do Związku Radzieckiego ${ }^{6}$

Cyrankiewicz obiecał natychmiast wpłynąć na rozpowszechnianie przez wydawnictwo „Wiedza” literatury radzieckiej i organizację jej tłumaczenia w Polsce.

W sprawozdaniu politycznym ambasady radzieckiej w Warszawie za rok 1947 stwierdzano, że

Poziom ideowy życia kulturalnego w Polsce wyraźnie odstaje od osiągniętych przez kraj sukcesów politycznych i ekonomicznych. Wychowana na tradycjach walki o wyzwolenie narodowe od caratu rosyjskiego i służąca antyradzieckim celom polskich rządów reakcyjnych w latach 1918-1939 inteligencja polska nie przebudowała jeszcze swojego pojmowania nowej sytuacji w Polsce i nowych stosunków polsko-radzieckich. (...) Najwięksi pisarze i poeci polscy wciąż jeszcze zajmują pozycję wyczekującą. Obecnie na takiej pozycji w dalszym ciągu pozostaje Parandowski (członek angielskiego PEN-Clubu) i po części nawet Zofia Nałkowska. Największy poeta polski Tuwim przychylnie wypo-

\footnotetext{
${ }^{3}$ Wostocznaja Jewropa $w$ dokumientach..., op. cit. t. 1, s. 245.

${ }^{4}$ Ibid., s. 696.

${ }^{5}$ Wostocznaja Jewropa $w$ dokumientach..., op. cit. t. 2, s. 337-338.

${ }^{6}$ Sowietskij faktor..., op. cit. s. 384.
} 
wiada się o nowej Polsce i Związku Radzieckim, lecz gryzie go jeszcze robak wątpliwości. Natarczywie dopytywał się Wandy Wasilewskiej, która przyjeżdżała do Warszawy w październiku 1947 roku, czy rzeczywistość radziecka odpowiada jego ideałom. Na razie nie napisał nic nowego (...).

Dalej w sprawozdaniu mówiło się o Dąbrowskiej, Pruszyńskim, Andrzejewskim („pisarz katolicki, wydał niedawno książkę Popiót i diament, w całości poświęconą PPR”). Iwaszkiewiczu, Kruczkowskim, Putramencie („twórczość Putramenta krytyka radziecka ocenia pozytywnie”), o „reakcyjnym repertuarze” teatru polskiego, który „świadczy o tym, że osiągnięcia PPR na froncie ideologicznym wciąż jeszcze są niewielkie"' $Z$ analizy wysnuwano wniosek o stanie kryzysowym kultury polskiej.

Należało gruntownie „przepłukać mózgi” inteligencji polskiej, której przedstawiciele, w tym również członkowie PPR, według sprawozdania ambasady, „nie pozbyli się jeszcze ideologii szlacheckiej ze swoich głów"7.

To „pranie mózgu” odbywało się różnymi metodami. Przykładowo, dla zwiększenia efektywności propagandy filmowej w latach 1946-1947 w ZSRR przygotowano polski dubbing dwóch filmów, jego jakość okazała się jednak zła:

Widzowie polscy — pisal do Moskwy przedstawiciel Soweksporffilmu w Warszawie - śmieją się nie tyle z wątku komediowego, ile ze złej polszczyzny, i w znacznej liczbie opuszczają salę przed końcem seansu 8 .

Tak samo mało skuteczne były również tandetne radzieckie broszury propagandowe, które zalegały półki księgarń polskich. W notatce służbowej z 16 grudnia 1946 o pracy przedstawicielstwa Sowinformbiura w Polsce pisano:

Efektywność propagandy radzieckiej w Polsce nie odpowiada wymaganiom momentu politycznego?.

Stosowano także organizacyjne środki oddziaływania na redaktorów prasy polskiej, którzy nie kwapili się z publikacją materiałów nadsyłanych ze Związku Radzieckiego. Tak na przykład 1 kwietnia 1948 roku przedstawiciel Sowinformbiura w Polsce Żyrnow oświadczył, że wszyscy redaktorzy, którzy nie zamieszczają w swoich pismach materiałów Sowinformbiura lub publikuja je w niedostatecznej ilości, będą zdjęci z zajmowanych stanowisk ${ }^{10}$.

\footnotetext{
${ }^{3}$ Archiwum Polityki Wewnętrznej Federacji Rosyjskiej, zespól 0122, rejestr 30a, teczka 247, sprawa 3, karta $56,64,73-74$.

${ }^{8}$ Rosyjskie Centrum Przechowywania i Badania Dokumentów Historii Najnowszej (obecnie Rosyjskie Państwowe Archiwum Historii Spoleczno-Politycznej), zespól 17, rejestr 132, sprawa 251, karta 40.

${ }^{9}$ Rosyjskie Centrum Przechowywania i Badania Dokumentów Historii Najnowszej, zespół 17, rejestr 125, sprawa 509 , karta 4.

${ }_{10}$ Sowietskij faktor..., op. cit. s. 574.
} 
Wielkie znaczenie kierownictwo radzieckie nadawało publikowaniu w olbrzymich nakładach literatury marksistowsko-leninowskiej po polsku. W pisemnym raporcie dla sekretarza KC G. Malenkowa z 23 sierpnia 1949 roku pracownicy Wydziału Agitacji i Propagandy KC WKP(b) L. Smirnow i M. Morozow stwierdzali, że na polecenie Rady Ministrów ZSRR z 6 lutego 1949

...w roku bieżącym zamierzano wydrukować dla Polski, na bazie poligraficznej radzieckiej strefy okupacyjnej Niemiec, 5 milionów egzemplarzy dzieł klasyków marksizmu-leninizmu. Później, według wskazań KC WKP(b), wydawnictwo SWAG (Radzieckiej Administracji Wojskowej w Niemczech) powinno wydrukować w języku polskim 1 milion egzemplarzy Krótkiego kursu historii $W K P(b)$.

W raporcie tym mówiono również o literaturze pięknej:

Przejrzeliśmy przybliżony spis utworów artystycznych, które polskie wydawnictwa zamierzają wydrukować w 1949 roku (...). Ogólnie spis ten nie wywołuje sprzeciwu. Większość książek to utwory pisarzy radzieckich: Gorkiego, Simonowa, Fiedina, Wasilewskiej i innych. W spisie są też książki autorów polskich: Mickiewicza, Tuwima i Prussa [tak $w$ tekście]"11.

Z Mickiewicza proponowano wydać Pana Tadeusza, z Tuwima - Stonia Trąbalskiego i Lokomotywę, z Prusa - Faraona i Placówkę.

Autorzy raportu uważali za celowe zakazać polskim wydawnictwom opublikowania książki Grosmana Śmierć poety (o Puszkinie), ponieważ wypacza ona wizerunek „geniusza oryginalnej kultury rosyjskiej”.

Po rfoku 1948 natarcie radzieckie na polskim froncie ideologicznym i kulturalnym rozwija się na wielką skalę. Tak oto 21 marca 1949 roku kierownik IV Europejskiego Wydziału Ministerstwa Spraw Sagranicznych ZSRR S. Kirsanow w opracowaniu Propozycje nasilenia wplywów radzieckich na życie kulturalne Polski, Czechostowacji i innych krajów Europy Wschodniej stwierdza, że znaczna część inteligencji polskiej

...nie poszła jeszcze drogą wsparcia nowego ustroju demokracji ludowej, chodzi jeszcze na pasku najwyżej postawionej burżuazyjnej reakcji, powiązanej tysiącznymi nićmi z reakcyjnymi kręgami imperialistycznych krajów zachodnich.

Jego zdaniem szczególnie silny jest wpływ inteligencji reakcyjnej w polskim szkolnictwie wyższym, a w szkołach podstawowych i średnich — dziwi się Kirsanow — „nadal trwa nauka religii” („do sich por priepodajetsia zakon bożij”). W związku z tym autor proponuje niezwłocznie podjąć szereg kroków, między innymi:

"Państwowe Archiwum Federacji Rosyjskiej, zespól 5446, rejestr 53, sprawa 529, karta 9. 
Utworzyć przy Wyższej Szkole Partyjnej i Akademii Nauk Społecznych wydziały kształcenia marksistowskiej kadry krajów demokracji ludowej (...);

Wprowadzić praktykę kierowania naukowców i wykładowców radzieckich do pracy na wyższych uczelniach krajów demokracji ludowej (wykłady, kursy specjalistyczne, kierowanie katedrami) (...);

Zwrócić uwagę naszych przyjaciół w krajach demokracji ludowej na konieczność zdecydowanej likwidacji resztek dawnej zależności od zachodnich państw imperialistycznych — różnego rodzaju konwencji kulturalnych, zagranicznych instytucji i szkół kulturalnych ${ }^{12}$.

Podobne propozycje zostały skierowane przez Ministerstwo Spraw Zagranicznych ZSRR do Komitetu Centralnego WKP(b):

1. Periodycznie, w przybliżeniu dwa razy do roku, zwoływać w KC WKP(b) narady wszystkich resortów, które mogą pomóc w sprawie nasilenia wpływów kulturalno-politycznych ZSRR w Polsce i innych krajach demokracji ludowej, dla omówienia podstawowych przedsięwzięć, zaplanowanych przez resorty na pół roku — rok w tej dziedzinie. (...);

2. Ustalić praktykę delegowania naukowców i wykładowców radzieckich do pracy w szkolnictwie wyższym Polski (i innych krajów demokracji ludowej) na dłuższe okresy (pół roku - rok);

3. Organizować przy Akademii Nauk Społecznych wydział kształcenia kadry marksistowskiej krajów demokracji ludowej, uzgadniając z Komitetami Centralnymi partii komunistycznych i robotniczych staranną selekcję personalną kandydatów kierowanych na studia na tym wydziale ${ }^{13}$

Zauważmy, że szkolenie i przeszkalanie polskiej kadry partyjnej różnych poziomów przekształciły się w stały system. Przykładowo 7 maja 1949 roku kierownik Wydziału Polityki Wewnętrznej KC WKP(b) W. Grigorian meldował Stalinowi o przybyciu na 3-4 tygodnie do Wyższej Szkoły Partyjnej przy KC WKP(b) grupy ponad pięćdziesięciu absolwentów Wyższej Szkoły Partyjnej przy KC PZPR; 5 maja 1950 — o wizycie w ZSRR sześćdziesięcioosobowej grupy absolwentów jednorocznej szkoły partyjnej przy KC PZPR; 16 sierpnia 1950 roku do ZSRR przyjechały dwie grupy z R. Zambrowskim na czele dla zapoznania się z praca KC WKP(b), komitetami centralnymi partii komunistycznych republik zwiazkowych, komitetów obwodowych i rejonowych; 24 sierpnia 1951 roku w tym samym celu przyjechała grupa sekretarzy wojewódzkich PZPR i przewodniczących wojewódzkich rad narodowych ${ }^{14}$. Ten system wychowania kadry utrzymał się aż do rozkładu bloku radzieckiego.

12 Wostocznaja Jewropa $w$ dokumientach..., t. 2, op. cit. s. 40-41.

13 Archiwum Polityki Wewnętrznej Federacji Rosyjskiej, zespół 021, rejestr 3, teczka 8, sprawa 192, k. 2-5.

14 Rosyjskie Centrum Przechowywania i Badania Dokumentów Historii Najnowszej, zespół 82, rejestr 2, sprawa 1299 , karty $17,27-28,42,68$. 
Dla oddziaływania na inteligencję polską wykorzystywano wizyty w Polsce przedstawicieli kultury radzieckiej. 5 czerwca 1948 roku radca ambasady radzieckiej Jakowlew radzi J. Bermanowi wykorzystać przyjazd do Polski kompozytorów Chrennikowa i Szaporina „dla wyjaśnienia polskim kręgom muzycznym sensu dyskusji w ZSRR o wypaczeniach formalistycznych w muzyce". Berman obiecał dać odpowiednie polecenie członkom aparatu partyjnego z KC PZPR i wiceministrowi kultury i sztuki W. Sokorskiemu w tej sprawie, jak też w sprawie druku materiałów o Związku Radzieckim w wydawnictwie „Współpraca”. Obiecał również zrobić porządek w stowarzyszeniu „Film Polski”, które, zdaniem ambasady radzieckiej, „zachwaszczone jest przez elementy wrogie sprawie przyjaźni polsko-radzieckiej”.

Charakterystyczna jest irytacja ambasadora radzieckiego w Polsce W. Lebiediewa w raporcie o konferencji teoretycznej, poświęconej językoznawczym pracom Stalina, która odbyła się w Warszawie 4 grudnia 1950 roku. Oskarża on „polskich naukowców burżuazyjnych, specjalistów językoznawców, przybyłych z Krakowa" - profesorów Nitscha, Doroszewskiego, Stiebera, Urbańczyka, Lehra-Spławińskiego (czyli kwiat lingwistyki polskiej) o to, że „wykorzystali oni udostępnioną im trybunę, żeby rozwinąć własny sztandar w obronie burżuazyjnej lingwistyki idealistycznej, którą reprezentują"16.

Sporo kłopotów dostarczało przywódcom radzieckim i polskim radio zachodnie. Żeby mu przeciwdziałać, 24 października 1951 roku Rada Ministrów ZSRR przyjęła postanowienie podpisane przez Stalina O stworzeniu zaktóceń na terytorium Polski przeciwko antypolskiej propagandzie radiowej. Ministerstwu Łączności ZSRR kazano radzieckimi środkami technicznymi zorganizować zakłócenia radia zachodniego na falach krótkich na terenie Polski i pomóc rządowi polskiemu w stworzeniu zakłóceń na falach średnich ${ }^{17}$.

Organy radzieckie w Moskwie i w Polsce aktywnie ingerowały w politykę kadrową władz polskich. 13 lutego 1950 ambasador Lebiediew przekazał Bierutowi wiadomość o tym, że Moskwa odmówiła wizy „działaczom literatury polskiej Żółkiewskiemu i Fedeckiemu”. w odpowiedzi Bierut oświadczył, że nie kojarzy postaci Fedeckiego z przeszłości, lecz ujął się za Żółkiewskim, który, jego zdaniem, „usilnie pracuje nad tym, żeby zostać dobrym marksistą i dobrym literatem”. „Chciałoby się — oznajmiał dalej Bierut - żeby towarzysze radzieccy pomogli nam go wychować" 18 .

Wstawiennictwo Bieruta nie pomogło Żółkiewskiemu, którego w ZSRR zawsze podejrzewano o wrogość. W tak zwanym archiwum prezydenckim w Moskwie znajduje się dokument $z$ uwagami Stalina na marginesie, wysłany 18 lutego 1952 roku przez pomocnika sekretarza generalnego MSZ ZSRR, W. Kuzniecowa do Stalina, Mołotowa, Berii, Malenkowa i Bułganina. Jest to zapis jego rozmowy z córką J. Marchlewskiego, w której tak opiniowała Zółkiewskiego:

\footnotetext{
15 Sowietskij faktor..., op. cit. s. 586-587.

${ }^{16}$ Wostocznaja Jewropa $w$ dokumientach..., op. cit. t. 2, s. 462.

17 Ibid., s. 642.

${ }^{18}$ Ibid., s. 301.
} 
Na czele Instytutu Badań Literackich stoi niejaki Żółkowski [tak w dokumencie], dziennikarz sanacyjny. W instytucie tym udaja, że przygotowują marksistowska historię literatury polskiej. Żółkowski to zręczny oszust, korzysta z terminologii marksistowskiej, ale sam nie wierzy w to, co mówi ${ }^{19}$.

W tej samej rozmowie stwierdzono również, że Leon Gomolicki to „były białogwardzista", że „w wydawnictwie "Książka i Wiedza» siedzą dawni i dzisiejsi wrogowie, szpiedzy i dywersanci”, że „kierownikiem Wydziału Historii Partii jest niejaki Daniszewski, którego prawdziwe nazwisko brzmi Kirschbaum; jego ojciec w przedwojennej Polsce był bogatym bankierem i posłem na sejm", oraz że Daniszewski ma w Moskwie przyjaciela, niejakiego Millera z Instytutu Słowianoznawstwa Akademii Nauk ZSRR, który proteguje go w Wielkiej Ensyklopedii Radzieckiej i tak dalej.

Dobitnym przykladem bezceremonialnej ingerencji radzieckiej w wewnętrzne sprawy Polski - nie tylko w dziedzinie kultury — jest list ambasadora ZSRR w Polsce G. Popowa do W. Mołotowa z 25 sierpnia 1953 o polskim hymnie narodowym, gdzie czytamy między innymi:

Polska Republika Ludowa dotychczas nie ma nowego hymnu narodowego, adekwatnego w treści do nowej epoki w życiu Polski. (...) Tekst obecnego hymnu jest absolutnie przestarzały politycznie, a treść antyrosyjska i szowinistyczna.

Dalej ambasador powołuję się na rozmowę z Bierutem, Rokossowskim i Cyrankiewiczem, którzy zgodzili się z tym, że hymn jest przestarzały i należy napisać nowy, „lecz skarży się ambasador — sprawa nowego hymnu w Polsce dotychczas nie została rozwiązana" ${ }^{20}$.

Rozpatrując ingerencję radziecką w życie kulturalne Polski, trzeba jednak uwzględnić także liczne kompromisy $z$ władzą radziecką i polską, na które $-z$ różnych przyczyn — szła większość inteligencji polskiej. Oceniając zaś rozpowszechnianie w Polsce tamtych lat kultury rosyjskiej i radzieckiej, trzeba brać pod uwagę, że często tymi samymi kanałami rozchodziła się nie tylko tandetna produkcja propagandowa, lecz i wielkie osiągnięcia klasycznej rosyjskiej spuścizny literackiej, muzycznej i teatralnej. Polscy widzowie i słuchacze mogli zapoznawać się również ze sztuką wybitnych pianistów i skrzypków z Rosji, z rosyjskim baletem i teatrem, występującymi gościnnie w Polsce. Ich twórczość podtrzymywała prestiż kultury rosyjskiej, mimo wszystkich ograniczeń polityki i estetyki stalinowskiej. W samej Polsce prawdziwi koneserzy kultury rosyjskiej często omijali dogmaty i zakazy instytucji radzieckich, Tak na przykład w 1947 roku ukazała się w Polsce antologia poezji rosyjskiej XIX i początku XX wieku w opracowaniu M. Jastruna i S. Pollaka, z przedmową L. Gomolickiego.

${ }^{19}$ Ibid., s. 700-701.

${ }^{20}$ Archiwum Polityki Wewnętrznej Federacji Rosyjskiej, zespół 0122, rejestr 36, teczka 305, sprawa 77, karta 171-172. 
Zamieszczono w niej wiersze poetów zakazanych w ZSRR, co spowodowało niezadowolenie referentów sowieckiego WOKS (Towarzystwa Łączności Kulturalnej z Zagranica) ${ }^{21}$.

Trzeba dodać również, że propaganda radziecka przez swój lichy poziom często w rzeczywistości pracowała przeciwko wyznaczonym celom ideologicznej obróbki polskiej opinii publicznej.

Zakrojona na wielką skalę, obróbka ta okazała się w gruncie rzeczy mało skuteczna, co udowodniły dalsze wydarzenia najnowszej historii Polski. Trwałym zabezpieczeniem przeciw ideologicznemu naciskowi pozostawały narodowe tradycje kulturalne, których nie udało się wykorzenić ze świadomości ogółu ani dostosować ich do potrzeb ideologii komunistycznej.

${ }^{21}$ Państwowe Archiwum Federacji Rosyjskiej, zespół 5283, rejestr 17, sprawa 127. 